Abstract-We analyzed the macroscopic and histological maturity data of Argentine hake (Merluccius hubbsi) collected off Patagonia in the spawning area of the Patagonian stock of this species between 2005 and 2014 to determine the frequency of skipped spawning. This study revealed that the only evidence of skipped spawning observed for Argentine hake was the resting stage. Analysis of 58,891 adult females of Argentine hake sampled during their reproductive peak indicates that, annually, between $6 \%$ and $22 \%$ of them had skipped spawning. These females were located mostly in the periphery of the spawning area, in deeper $(>90 \mathrm{~m})$ and colder waters $\left(7-8^{\circ} \mathrm{C}\right)$. Individuals that had skipped spawning had a more intense feeding activity and a better nutritional condition ( $K=0.68-0.75)$ than females collected in the main spawning area according to the Fulton's condition index. In contrast, postspawning females showed the poorest condition $(K=0.62-0.68)$ because of the energy cost involved with reproduction. Females that had skipped spawning were mostly young individuals with a modal age of 3 years and a modal size of $38 \mathrm{~cm}$ TL. These results indicate that a significant proportion of females that had completed their first annual spawning could skip the next spawning event and stay on the periphery of the reproductive area to feed.

Manuscript submitted 2 March 2016. Manuscript accepted 29 June 2016. Fish. Bull. 114:397-408 (2016). Online publication date: 26 July 2016. doi: 10.7755/FB.114.4.3

The views and opinions expressed or implied in this article are those of the author (or authors) and do not necessarily reflect the position of the National Marine Fisheries Service, NOAA.

\title{
Skipped spawning in the Patagonian stock of Argentine hake (Merluccius hubbsi)
}

\author{
Gustavo J. Macchi (contact author)1,2 \\ Marina V. Diaz ${ }^{1,2}$ \\ Ezequiel Leonarduzzi ${ }^{2}$ \\ María Inés Militelli, ${ }^{1,2}$ \\ Karina Rodrigues ${ }^{1,2}$ \\ Email address for contact author: gmacchi@inidep.edu.ar \\ 1 Consejo Nacional de Investigaciones Científicas y Técnicas (CONICET) \\ Instituto de Investigaciones Marinas y Costeras (IIMyC) \\ Deán Funes 3250 \\ B7602HSA Mar del Plata \\ Buenos Aires, Argentina \\ 2 Instituto Nacional de Investigación y Desarrollo Pesquero (INIDEP) \\ Paseo Victoria Ocampo Número 1 \\ B7602HSA Mar del Plata \\ Buenos Aires, Argentina
}

Recruitment (i.e., the number of progeny that will survive each year to be incorporated into the population) depends (in most traditional fishery assessment models) directly on the abundance of the parental stock, or spawning stock biomass (SSB), calculated from the maturity ogive (Mace and Sissenwine, 1993; Rodgveller et al., 2016). In iteroparous fish species that spawn repeatedly, it is assumed that once they have reached sexual maturity, all individuals reproduce on an annual cycle, i.e., the total adult fraction of the population. In recent years, evidence from many fish species indicates that this pattern does not occur for at least part of the spawning stock (Rideout and Tomkiewicz, 2011). This phenomenon, known as skipped spawning (SS), implies that during the breeding season a proportion of the adult population does not spawn during that year. This "irregularity" in the reproductive cycle would have consequences for the estimate of the SSB because not every adult would contribute to the reproductive potential of the popula- tion. This potential issue with SSB estimates could introduce greater variability in the stock-recruitment relationship. Including the nonreproductive fish in calculations of the SSB could lead to an overestimation of the number of spawning fish and, therefore, would lead to an overestimation of expected recruitment. The degree of effect would depend on the fraction of the population affected by skipped spawning, the magnitude of which may vary between years.

Different hypotheses explain the origin of skipped spawning, but most of them are associated with food deficiencies that affect energy storage before spawning activity or with unfavorable physical conditions that prevent or delay ovaries from ripening (Holmgren, 2003; Jørgensen et al., 2006; Rideout et al., 2006; Rideout and Tomkiewicz, 2011). It has been suggested that, in general, poor nutritional conditions may not allow fish to accumulate enough energy to support egg production in consecutive years (Kennedy, 1953; Dutil, 1986). However, the main problem in determining the origin of this 
"anomaly" in the annual spawning cycle is the lack of reliable historical information about a stock (i.e., data from a histological examination of gonads, as well as condition indices during the reproductive cycle) and on the oceanographic or physical features associated with the population data. Moreover, to be able to estimate a reliable index that represents the fraction of the population that does not reproduce during the year, data are needed for the entire distribution of the species, collected at different times during the reproductive cycle. For this reason, despite evidence of skipped spawning for several species, there are very few cases where this information has been incorporated into assessment models (Rideout et al., 2011). Rideout et al., 2005 , on the basis of the morphological examination of the ovaries, have suggested that there are 3 categories of skipped spawning depending on when maturation is interrupted: retaining, reabsorbing, and resting.

Skipped spawning has been associated primarily with species that have determinate annual fecundity (Rideout and Tomkiewicz, 2011), which is characterized by a fixed fecundity at the onset of the spawning season, when recruitment of previtellogenic oocytes to the secondary growth stage ceases (Hunter et al., 1992). On the other hand, in species with indeterminate annual fecundity, unyolked oocytes mature continuously and are spawned throughout an extended reproductive season. This pattern of oocyte development and the extended breeding season of such species make it difficult to evaluate the reproductive history of a fish and to determine whether spawning has been skipped. Nevertheless, the identification of adult fish with ovaries in the regenerating stage during the reproductive season and the presence of adults outside of the spawning area were considered evidence of skipped spawning in fish with indeterminate annual fecundity (Rideout and Tomkiewicz, 2011).

The Argentine hake is a batch spawner with indeterminate annual fecundity (Macchi et al., 2004). In the Argentine sea, the Patagonian stock, located from $41^{\circ} \mathrm{S}$ to $55^{\circ} \mathrm{S}$ and with a biomass of about $1,000,000$ metric tons, is economically the most important fishery resource according to a virtual population analysis in 2013 (Villarino and Santos ${ }^{1}$ ). The reproductive activity of this stock occurs during austral spring and summer (from November through March) peaks in January (Macchi et al., 2004, Pájaro et al., 2005). Although on several occasions the presence of nonreproductive adult individuals has been noted during the spawning season of Argentine hake (Macchi et al., 2004), information on the incidence of skipped spawning has not been reported for this species. The main goal of this study was to analyze the phenomenon of skipped spawning in the

\footnotetext{
1 Villarino, M. F., and B. A. Santos. 2014. Evaluación del estado de explotación del efectivo sur de $41^{\circ} \mathrm{S}$ de la merluza (Merluccius hubbsi) y estimatión de las captura biológicamente aceptable para 2015. INIDEP Inf. Tec. Of. 30, 39 p. Instituto Nacional de Investigación y Desarrollo Pesquero, Mar del Plata, Argentina.
}

Patagonian stock of Argentine hake, from macroscopic and histological analyses of samples collected during research surveys during the main reproductive season of this stock over a period of 10 years. Specific objectives were 1) to determine the dominant category of skipped spawning in Argentine hake, 2) to estimate the incidence of this phenomenon in the population, and 3) to study the relationship of skipped spawning with the size and nutritional status of fish, as well as its possible relationship to environmental factors.

\section{Materials and methods}

\section{Sample collection and laboratory processing}

During 10 research surveys conducted by the Instituto Nacional de Investigación y Desarrollo Pesquero (INIDEP), carried out in the north Patagonian area in Argentina between 2005 and 2014, samples of Argentine hake were obtained from hauls of bottom trawls. These surveys were performed during the time of peak spawning of the Patagonian stock (January) in the main reproductive area of Argentine hake and in the nursery ground of this species in San Jorge Gulf (Fig. 1). Although the area sampled during these surveys is smaller than the overall area of the distribution of the Patagonian stock of Argentine hake, we are confident that most of the adult population was sampled because individuals congregated in shallow coastal waters of the north Patagonia area during the peak spawning period (Macchi et al., 2007). Trawling was conducted along transects regularly separated by about $37 \mathrm{~km}(20 \mathrm{nmi})$ and was oriented perpendicularly to the coastline. The same stations were visited annually. Specimens of Argentine hake were captured at depths between 50 and $120 \mathrm{~m}$ by employing a bottom trawl with a mouth width of about $20 \mathrm{~m}$, a height of about $4 \mathrm{~m}$, and a net with 20-mm mesh at the inner lining of the codend. At each sampling station, salinity and temperature data were collected with an SBE 19 SeaCAT Profiler CTD2 (SeaBird Electronics Inc., Bellevue, WA). Data series were filtered and reduced to values of temperature and salinity to a 1 meter interval approximately.

Samples of Argentine hake were weighed, and total lengths (TLs in centimeters), sex, and maturity stage (Table 1) were recorded for each fish. A visual maturity key of 5 stages was used: 1) immature, 2) developing, 3) spawning, 4) postspawning or spent, and 5) resting or recovering (Macchi and Pájaro, 2003). Because the phenomenon of skipped spawning involves adult females, only data from fish in maturity stages $2-5$ were analyzed (Table 2). In addition, complementary biological data collected from subsamples of Argentine hake were also used. These data included information on the individual total weight (TW) in grams and on the degree

\footnotetext{
${ }^{2}$ Mention of trade names or commercial companies is for identification purposes only and does not imply endorsement by the National Marine Fisheries Service, NOAA.
} 


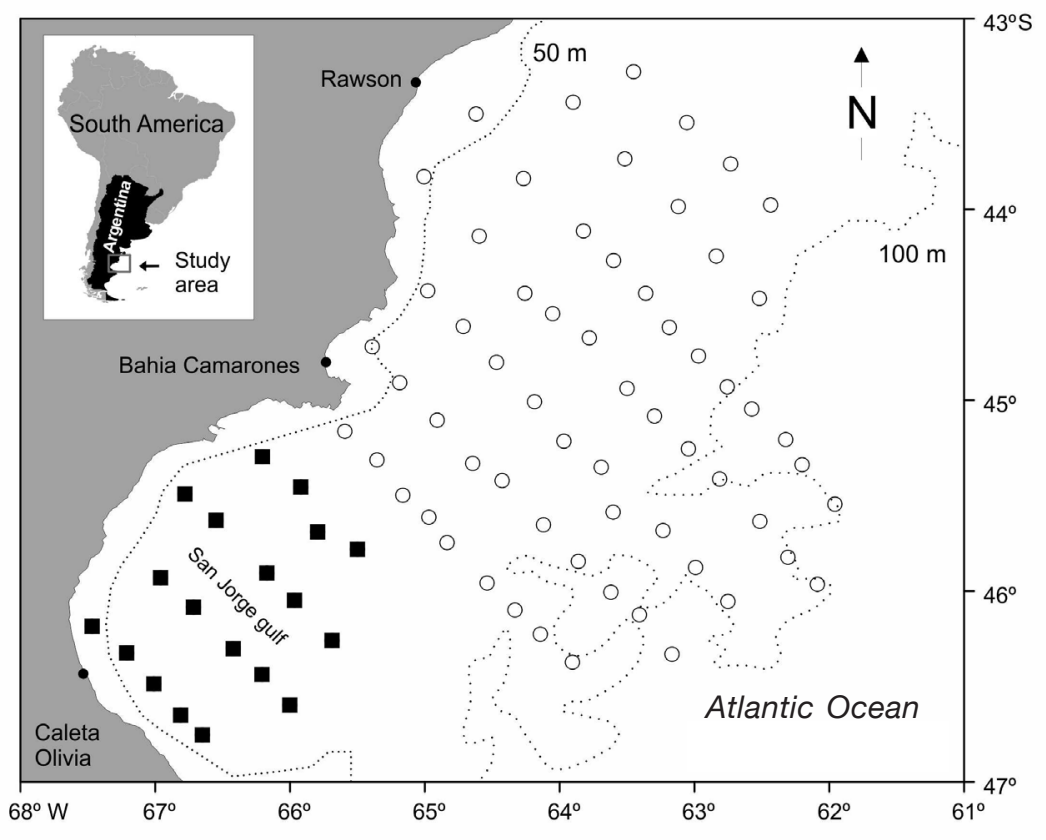

Figure 1

Locations where Argentine hake (Merluccius hubbsi) were collected during January from 2005 through 2014 in waters of the north Patagonian area off Argentina. Open circles indicate sampling locations in the area of Argentine hake reproduction, and black squares indicate sampling locations in the nursery area for juvenile Argentine hake in San Jorge Gulf. of stomach fullness (Table 2). Moreover, from theses subsamples, we collected sagittal otoliths for age determination (Table 2). Ages were determined by the methods described by Renzi and Pérez (1992).

The macroscopic maturity scale was validated by histological analysis of 11,494 gonads of adult females collected from different trawl hauls and preserved in $10 \%$ formalin during the research cruises (Table 2). Ovaries were weighed to the nearest $0.1 \mathrm{~g}$ to obtain gonad weight (GW), and a portion (about $2.0 \mathrm{~g}$ ) of each gonad was removed, dehydrated in ethanol, cleared in xylol, and embedded in paraffin. Sections were cut at a 5 - $\mu \mathrm{m}$ thickness and stained with Harris's hematoxylin, followed by eosin counterstain. Histological staging of ovaries was based on the stage of oocyte development and on the occurrence of postovulatory follicles and atresia, described by Macchi et al. (2004) and Brown-Peterson et al. (2011).

\section{Data analysis}

To estimate the incidence of skipped spawning from the macroscopic information, we calculated the percentage of rest-

\section{Table 1}

Visual maturity scale (1-5) and microscopic characteristics of the different stages in the reproductive cycle of female Argentine hake (Merluccius hubbsi) collected from the Patagonian stock during 2005-2014. Comparison with the phases of reproductive development described by Brown-Peterson et. al. (2011). The last column shows which females are in reproduction during the season. POFs=postovulatory follicles.

\begin{tabular}{|c|c|c|c|c|}
\hline \multicolumn{2}{|c|}{ Maturity stage } & \multirow{2}{*}{$\begin{array}{l}\text { Main histological features } \\
\text { Only oogonias and oocytes in primary } \\
\text { growing stage. Some little cortical alveoli } \\
\text { can be observed. Thin and transparent } \\
\text { ovarian tunica. }\end{array}$} & \multirow{2}{*}{$\begin{array}{l}\text { Brown-Peterson } \\
\text { et al. (2011) }\end{array}$} & \multirow{2}{*}{$\begin{array}{c}\begin{array}{c}\text { Reproduction } \\
\text { during season }\end{array} \\
\text { No reproduction }\end{array}$} \\
\hline 1 & Immature & & & \\
\hline \multirow[t]{2}{*}{2} & Developing & $\begin{array}{l}\text { Oocytes in secondary vitellogenesis present. } \\
\text { Atresia can be observed. }\end{array}$ & Developing & Reproduction \\
\hline & & $\begin{array}{l}\text { Yolked oocytes, with or without POFs. } \\
\text { Atresia can be present }\end{array}$ & $\begin{array}{l}\text { Spawning capable } \\
\text { (mature) }\end{array}$ & Reproduction \\
\hline 3 & Spawning & $\begin{array}{l}\text { Hydrated oocytes, with or without POFs. } \\
\text { Atresia can be present. }\end{array}$ & $\begin{array}{l}\text { Spawning capable } \\
\text { (spawning) }\end{array}$ & Reproduction \\
\hline 4 & Postspawning & $\begin{array}{l}\text { Flaccid ovaries with abundant atresia of } \\
\text { oocytes in vitellogenesis. POFs and residual } \\
\text { hydrated oocytes may be present. }\end{array}$ & Regressing & Reproduction \\
\hline 5 & Resting & $\begin{array}{l}\text { Only oocytes in primary growing stage. } \\
\text { Thick ovarian tunica. }\end{array}$ & Regenerating & Skipped spawning \\
\hline
\end{tabular}




\section{Table 2}

Number of samples and subsamples of adult female Argentine hake (Merluccius hubbsi), as well as the number of ovaries that were analyzed for this study. Fish were obtained from the Patagonian stock during research surveys conducted off Argentina in January between 2005 and 2014 .

\begin{tabular}{|c|c|c|c|}
\hline Year & Samples & Subsamples & $\begin{array}{l}\text { Ovaries for } \\
\text { histological } \\
\text { examination }\end{array}$ \\
\hline 2005 & 4879 & 1253 & 1263 \\
\hline 2006 & 3110 & 1766 & 1388 \\
\hline 2007 & 5067 & 1507 & 1253 \\
\hline 2008 & 5154 & 1163 & 1203 \\
\hline 2009 & 6412 & 1163 & 1223 \\
\hline 2010 & 7558 & 1434 & 1192 \\
\hline 2011 & 4446 & 1036 & 731 \\
\hline 2012 & 7076 & 2112 & 1261 \\
\hline 2013 & 7763 & 1947 & 1093 \\
\hline 2014 & 5810 & 1944 & 887 \\
\hline
\end{tabular}

ing females (Table 1, maturity stage 5) within the total number of adult females (Table 1, maturity stages 2-5) for each sample, and that percentage was weighted by the abundance of Argentine hake (number of individuals $/ \mathrm{km}^{2}$ ) estimated for each trawl haul. This information was used to determine the spatial distribution of females that had skipped spawning and to establish a percentage of this phenomenon in the studied area during peak spawning. These data were contrasted with the spatial distribution of females in the spawning stage (with hydrated oocytes) obtained from each survey by using the same method.

Size distributions of individuals that had skipped spawning and reproductive females (i.e., developing, spawning, and postspawning) obtained from the visual and histological diagnoses were analyzed. Data collected during each survey were grouped in 2 categories, SS and reproductive females, which were compared by using a Kolmogorov-Smirnov test.

The age data obtained from the subsamples of Argentine hake were used to determine the age structure of females that had skipped spawning and reproductive females for each survey. These age distributions were compared in the same way as that used to compare total lengths, but only for the period 2005-2013, because 2014 data were not available.

Data on stomach contents were used to estimate Argentine hake feeding intensity associated with size, condition, and maturity of females. The percentage of stomachs with contents (SC) was estimated for females at different maturity stages, according to the visual scale, and for each survey. Individuals with everted stomachs as a consequence of pressure changes during capture were not used in this analysis.

To assess female nutritional condition and its re- lationship with maturity stages (histologically determined), we used the gonadosomatic index (GSI) and Fulton's condition factor $(K)$ for the samples collected during each survey. Because gutted weight data were not available, female TW (without ovaries) was used, according to the following equations:

$$
G S I=(G W /(T W-G W)) \times 100
$$

and

$$
K=(T W-G W) /\left(T L^{3}\right),
$$

where $G W=$ gonad weight; and

$$
T W=\text { total weight. }
$$

The mean values of GSI and $K$ obtained for the different maturity stages were compared by using the Kruskal-Wallis test, after analysis for normality of the data. Generalized linear modeling was used to determine if year, TL, $K$, or SC significantly influenced the probability of skipped spawning during the season. Skipped spawning was analyzed as a variable with a binomial distribution: females in the resting stage were nonreproductive (probability of skipped spawning $[\mathrm{SS}]=1$ ), and the other stages (developing, spawning, and postspawning) were considered representative of reproductive individuals (probability of $\mathrm{SS}=0$ ). Stomach contents were analyzed as a binary variable: with (1) or without (0) content. Therefore, year and SC were modeled as categorical variables, and TL and $K$ were modeled as continuous variables. In this study, to avoid problems of multicollinearity, age was excluded from the model because it was correlated with length. Analyses were restricted to adult fish greater than 32 cm TL because very few smaller fish were available; the length at maturity for the Patagonian stock is estimated to fall within 32-33 cm TL (Macchi et al., 2007).

The model had a logit link function and a binomial error structure. Pseudo values of the coefficient of determination $\left(r^{2}\right)$ were calculated to compare the proportions of the deviation by year, TL, $K$, and SC. This pseudo $r^{2}$ was constructed by expressing the deviance of the model as a proportion of deviance for the null model. Pseudo $r^{2}$ was estimated as the deviance in the model individually containing only the intercept (null deviance) minus the deviance after adding the mains factors, divided by the null deviance of the model containing only the intercept.

To analyze the effect of different variables in the model, the probability of skipped spawning was plotted against TL (by using a mean $K$ of 0.67 ) and against $K$ (by using a mean TL of $51.14 \mathrm{~cm}$ ) for females with or without SC. This analysis was performed with data from all sampled trawl hauls, but because the pattern was similar between years, we provide the results only from 2012, because that year was the year with the most sampling information (Table 2). All statistical analyses were conducted with the statistical software $\mathrm{R}$, vers. 3.2.3 ( $\mathrm{R}$ Core Team, 2015).

A principal component analysis was used to determine the possible relationship between the incidence of skipped spawning and some physical environmen- 


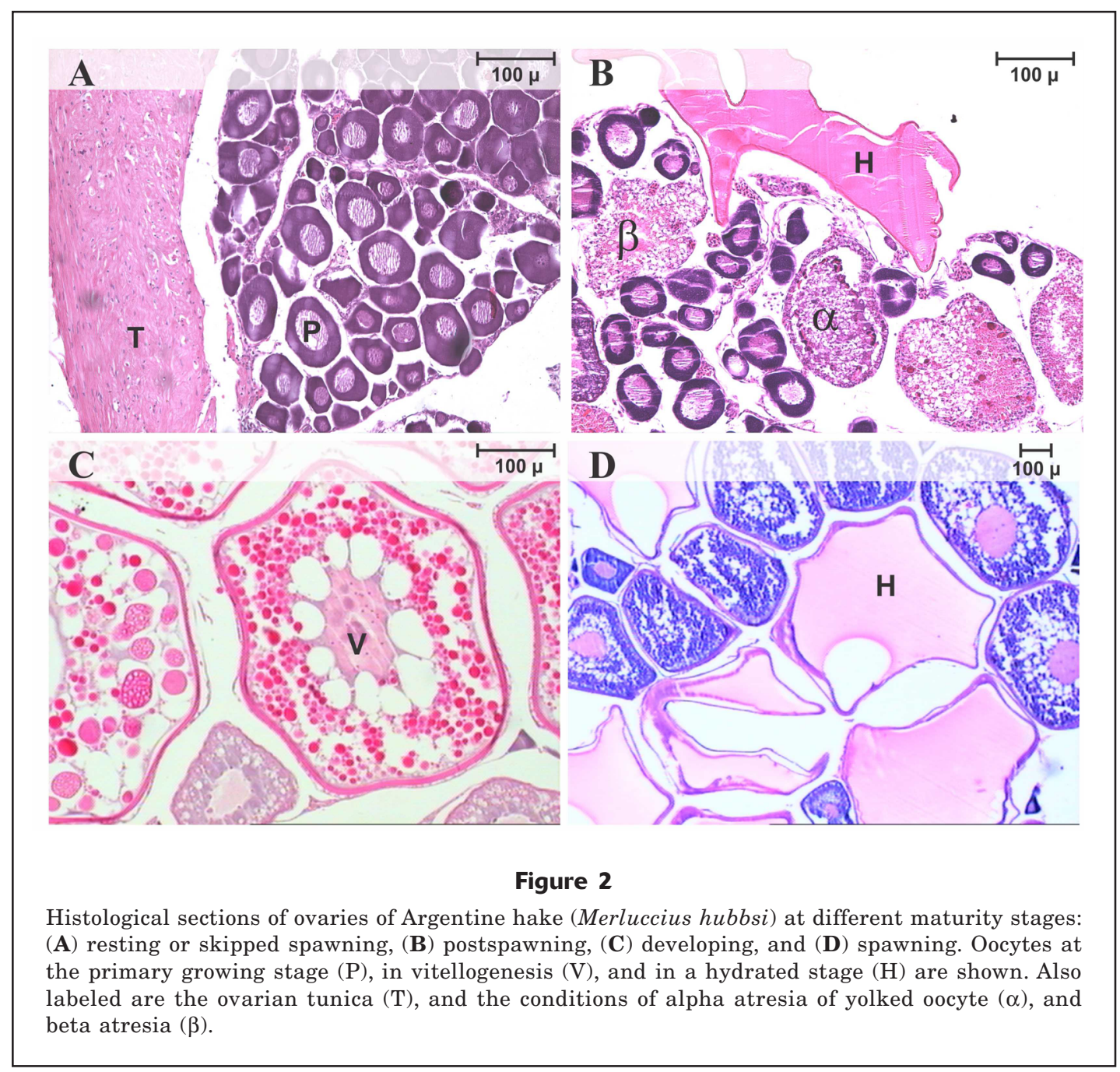

tal characteristics in the reproductive area. This study also included information on incidence of spawning, for comparison with data from females that had skipped spawning. The variables used were the percentages of females that had skipped spawning and the percentages of females in the spawning stage (with hydrated oocytes) and depth, temperature, and salinity estimated for the surface of the water and at the seafloor at sampling stations. Data collected in the nursery area of San Jorge Gulf (see Fig. 1) were excluded from this study. This analysis was performed with statistical software InfoStat, vers. 2009 (Grupo InfoStat, Facultad de Ciencias Agropecuarias, Universidad Nacional de Córdoba, Córdoba, Argentina).

\section{Results}

\section{Histological analysis and designation of maturity stages}

Histological analysis of 11,494 adult females, sampled during the peak spawning period (January) of the $\mathrm{Pa}$ - tagonian stock between 2005 and 2014, confirmed that of the 3 categories of skipped spawning (retaining, reabsorbing, and resting), only the resting stage was observed in Argentine hake. The main characteristic of this stage is that only oocytes in the primary growth stage can be observed in the ovaries, and there is no evidence of recent maturation (Fig. 2A). Unlike that in juveniles, the ovarian tunic in adults is markedly thick because of the completion of previous maturation cycles (Table 1). The other category of skipped spawning that has been described often for fish in the wild, reabsorbing or massive atresia, was not observed in Argentine hake. However, it was very common to see ovaries with oocytes in atresia, both in cortical alveoli or vitellogenesis stages, with different degrees of incidence, but all such cases corresponded with females with evidence of postspawning (Fig. 2B). The rest of the observed maturity stages included developing ovaries with oocytes in the second growth phase, with or without postovulatory follicles and low atresia (Fig. 2C), and active spawning, with hydrated oocytes, with or without postovulatory follicles (Fig. 2D). 

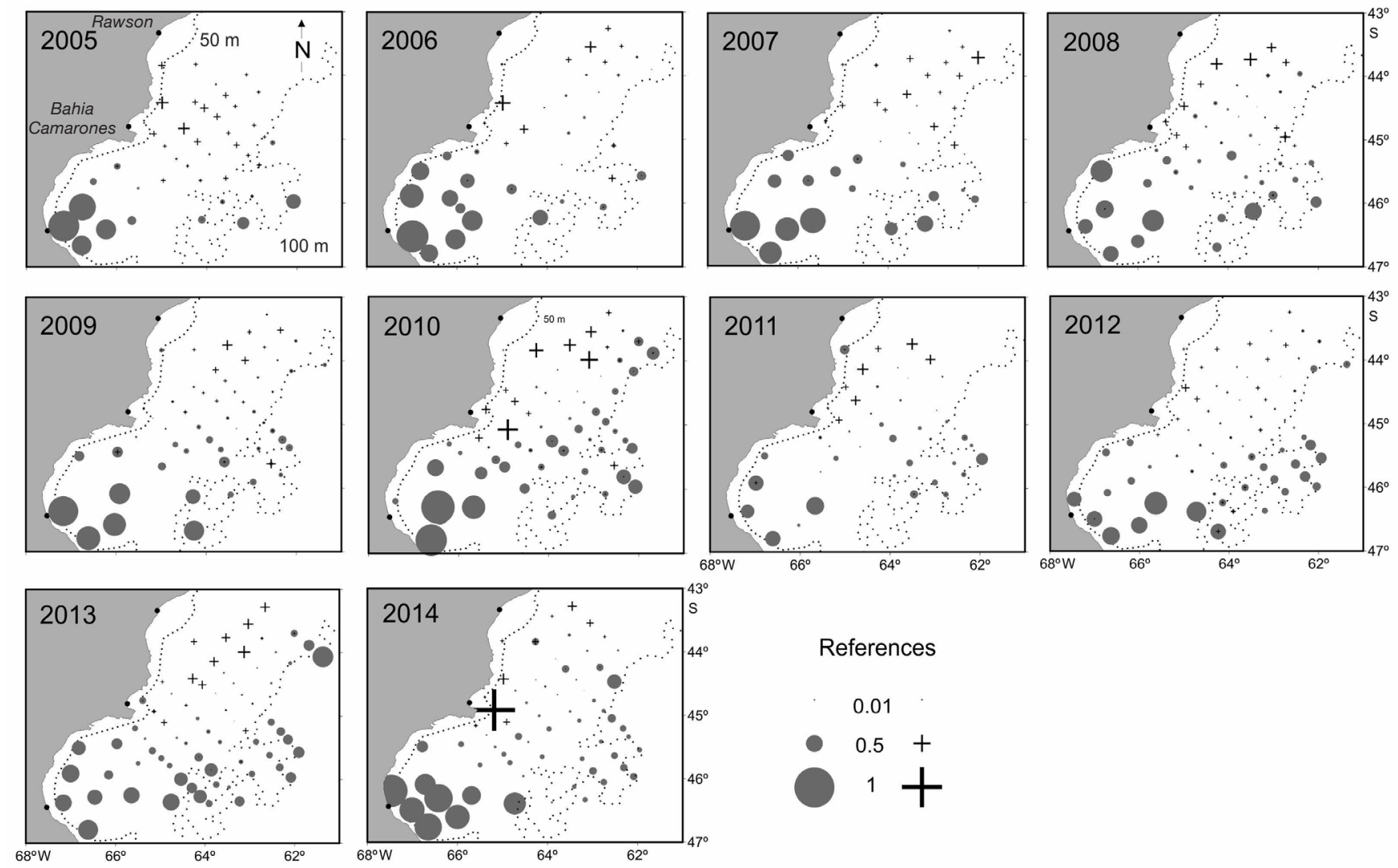

Figure 3

Spatial distribution of skipped spawning (gray circles) and spawning females (plus signs) of Argentine hake (Merluccius hubbsi) sampled in the north Patagonian area off Argentina during January from 2005 to 2014. The size of the symbols is proportional to the percentage of each stage weighted by the abundance of Argentine hake.

On the basis of our histological findings, we grouped adult female ovaries of Argentine hake into 4 main categories that represented the reproductive cycle: developing, spawning (with hydrated oocytes), postspawning, and resting. Table 1 shows how the features used in our histological analysis are related to the 5 stages of the visual maturity scale used in our macroscopic analysis and that the resting stage corresponds to skipped spawning.

\section{Spatial variation with skipped spawning and with spawning}

Macroscopic information collected during research surveys was used to analyze the annual spatial variation of females that had skipped spawning during the sampling period. This analysis also incorporated the percentages of spawning females (with hydrated oocytes) for comparison of the spatial variation of females that had skipped spawning and females that are in reproduction in the areas of spawning aggregation (Fig. 3).The maps show that females that had skipped spawning predominated in the external sector outside the spawning area of the Patagonian stock, with par- ticular abundance near the 100-m isobath and within the San Jorge Gulf. In January, when the main reproductive peak occurs, this spatial pattern remained relatively constant over the years.

The percentages of females that had skipped spawning for each survey within the area of reproductive activity of Argentine hake (see Fig. 1) ranged from $4 \%$ to $10 \%$, but when the data obtained in the San Jorge Gulf were incorporated, the percentages of females that had skipped spawning increased, ranging in most cases between $10 \%$ and 15\% (Fig. 4). In January 2006 and 2014, the percentage of such females for the whole area studied reached a value close to $22 \%$-a level that is probably due to the very large catches of Argentine hake that were recorded in the San Jorge Gulf during those years.

\section{Size and age of females that had skipped spawning}

Figure 5A shows the length distributions, grouped for all years of the study that correspond with females that had skipped spawning and with females in reproductive condition (developing, spawning, and postspawning) determined from visual analysis. In comparisons of both 


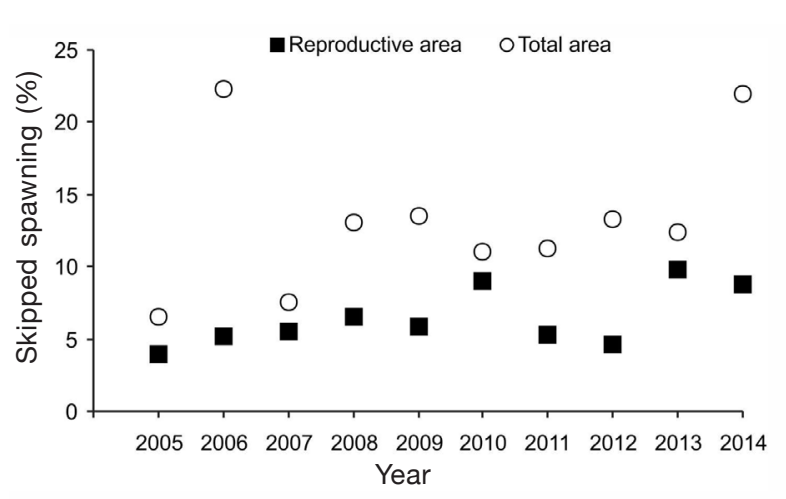

Figure 4

Percentages of female Argentine hake (Merluccius hubbsi) that had skipped spawning among all females of this species collected from the Patagonian stock, estimated for the reproductive area of this stock and for the total area sampled during the surveys conducted in January from 2005 through 2014.

distributions, highly significant differences $(P<0.001)$ were observed, and females that had skipped spawning were mostly composed of smaller specimens with a modal size of about $38 \mathrm{~cm}$ TL. On the other hand, reproductive females showed higher frequencies of individuals larger than $50 \mathrm{~cm}$ TL. To corroborate these results, the length distributions of females based on our histological results were also analyzed by grouping all surveys. The result was similar to that obtained by using the visual information: highly significant differences were observed in comparisons of the 2 distributions $(P<0.001)$ and nonreproductive females generally smaller than $50 \mathrm{~cm}$ TL.

The analysis of the age distribution obtained from subsamples of Argentine hake between 2005 and 2013 confirmed that females that had skipped spawning were primarily younger specimens with a modal age of 3 years and that the reproductive females were mainly represented by older individuals (Fig. 5B).

\section{Condition indices and feeding activity}

The mean GSI estimated for females that had skipped spawning was the lowest value given for females in a given maturity stage, followed by the GSI estimated for postspawning females, for developing females, and finally for spawning females (Table 3). The interannual variation in GSI values for different stages was relatively stable, with the widest range observed for spawning females.

When the nutritional condition, represented by $K$, was considered, females that had skipped spawning had mean values significantly higher $(P<0.0001)$ than those estimated for other maturity stages (Table 3 ). In comparison, female Argentine hake that had recently completed spawning showed the poorest condition.
Results of the analysis of stomach fullness in adult female Argentine hake during the reproductive peak indicated that both females that had skipped spawning and females that recently had completed spawning (postspawning) had a higher frequency of stomachs with contents (Fig. 6) and that females in the spawning stage had the lowest percentages of feeding activity. We observed an increasing trend in the frequency of stomachs with contents toward the end of the study period (2005-2014), particularly in the case of females that had skipped spawning.

Results from the generalized linear model confirmed that year, TL, $K$, and SC influenced the probability of skipped spawning during the reproductive season of the Patagonian stock of Argentine hake (Table 4). However, although these variables were statistically significant, the amount of variation explained by these factors was very low. The model explained only $10 \%$ of the variability for the probability of skipped spawning. Total length had a negative effect in the model, which provided evidence of an increase of the probability of skipped spawning in small $(<60 \mathrm{~cm}$ TL) adult females (Fig. 7A). In contrast, the effect of $K$ on the probability of skipped spawning trended positively, indicating that females that had skipped spawning were characterized by higher values and, therefore, better condition (Fig. 7B). The effect of SC, as a binary variable, indicated that the probability of skipped spawning is higher when females have food in their stomachs, than in its relationship with both $K$ and TL. Nevertheless, in the last case, the model results tended to merge when females were larger than $60 \mathrm{~cm}$ TL (Fig. 7A).

\section{Skipped spawning and physical variables}

The first 2 principal components of the principal component analysis explained $64 \%$ of total variance (Table 5 ). Principal component 1 explained $42 \%$ of total variance, and the variables most closely related to this component were the percentage of females that had skipped spawning and depth. Principal component 2 explained $22 \%$ of total variance, primarily the result of the percentage of spawning females and bottom temperature. This analysis indicated an opposite trend with the remaining studied variables (Table 5). An association between the highest proportion of females that had skipped spawning and deeper $(>90 \mathrm{~m})$ and colder $\left(7-8^{\circ} \mathrm{C}\right)$ waters was observed. Conversely, spawning females were primarily associated with shallower coastal waters, where temperatures near the bottom were higher $\left(9-13^{\circ} \mathrm{C}\right)$. Surface temperature and both bottom and surface salinity seem to have had no influence on the spatial distribution of female Argentine hake.

\section{Discussion}

By the year 2000, some authors mentioned the importance of considering the effect of skipped spawning 


\section{Table 3}

Mean values and confidence intervals (CIs) of the gonadosomatic index (GSI) and Fulton's condition factor $(K)$ estimated for each maturity stage, assessed by visual analysis, in adult female Argentine hake (Merluccius hubbsi) collected from the Patagonian stock between 2005 and 2014. Resting stage=skipped spawning.

\begin{tabular}{lcc}
\hline Visual maturity stage & Mean GSI (CI) & Mean $K(\mathrm{CI})$ \\
\hline Developing & $6.55(6.48-6.62)$ & $0.6724(0.6705-0.6743)$ \\
Spawning & $17.34(19.94-17.74)$ & $0.6540(0.6501-0.6579)$ \\
Postspawning & $2.70(2.64-2.76)$ & $0.6517(0.6481-0.6553)$ \\
Resting & $1.18(1.15-1.21)$ & $0.6937(0.6322-0.6418)$
\end{tabular}
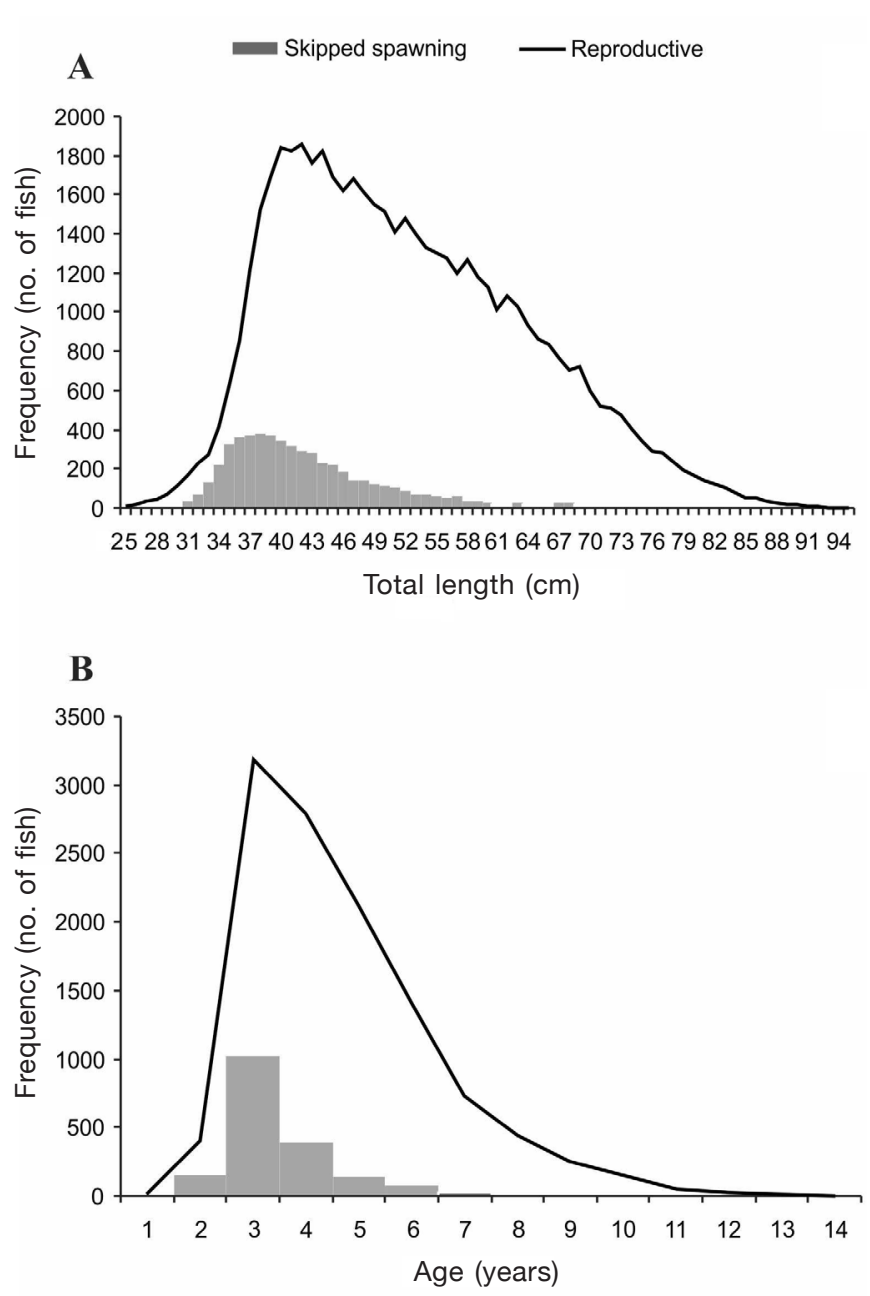

Figure 5

Grouped for all years analyzed, (A) size distribution and (B) age distribution of females of Argentine hake (Merluccius hubbsi) that had skipped spawning (gray bars) and reproductive (black line) Argentine hake sampled from the Patagonian stock off Argentina in January during 2005-2014. in estimates of the reproductive potential of fish stocks (Livingston et al., 1997; Trippel, 1999; Rideout et al., 2000). However, the analysis of this phenomenon in general has been focused largely on experimental studies, under controlled conditions, and on the morphological description of fish during this process (Rideout et al., 2005; Skjæraasen et al., 2009). In a recent review about skipped spawning, the presence of this phenomenon was reported for at least 31 species, including marine teleosts (demersal and pelagic), freshwater fish, and anadromous and catadromous species (Rideout and Tomkiewicz, 2011).

On the basis of when maturation is interrupted, 3 categories of skipped spawning have been suggested (Rideout et al., 2005): retaining, reabsorbing, and resting. In the first category, ovaries have completed the maturation process but eggs are not released because ovulation is stopped. This interruption usually happens in specimens kept in captivity and may be due to unfavorable physical or chemical conditions in the environment or to changes in the sex ratio or sexual behavior during the reproductive process. The second category includes those cases in which all oocytes in the growing phase are reabsorbed through massive follicular atresia after oogenesis is interrupted during vitellogenesis. In the resting category, the ovaries of adult specimens capable of spawning during the reproductive season remain in a nonreproductive condition.

Among the 3 categories described for the process of skipped spawning by Rideout et al. (2005), only the resting stage was observed in Argentine hake from the Patagonian stock in our study. Ovaries in the resting stage are characterized by the presence of oocytes in the primary growth stage and show no evidence of maturation or recent spawning. This diagnostic observed in adult specimens during the breeding peak in the repro- 


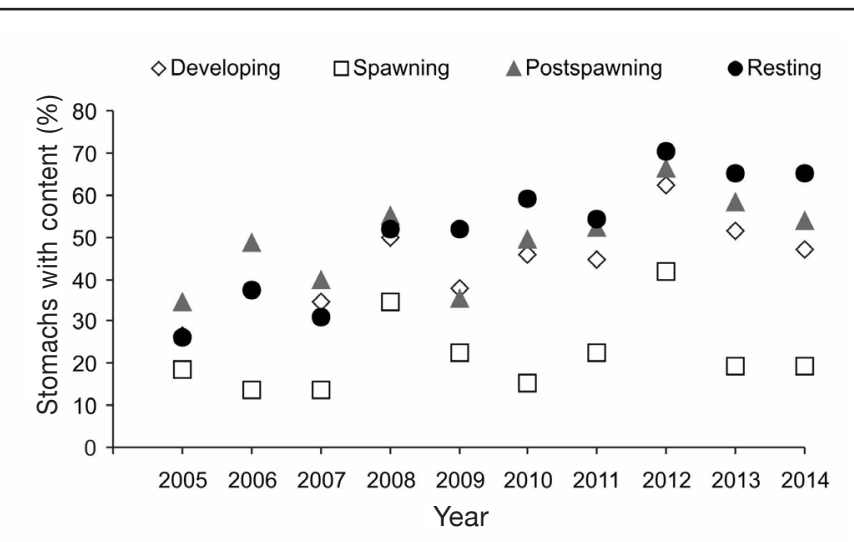

Figure 6

Annual variation of the mean percentages of stomachs with content for each maturity stage of female Argentine hake (Merluccius hubbsi) sampled from the Patagonian stock off Argentina during January between 2005 and 2014. Resting stage $=$ skipped spawning.

\section{Table 4}

Results of the generalized linear model, with the effect of year (Y), total length (TL), stomach content (SC), and Fulton's condition index $(K)$ on the probability of skipped spawning by Argentine hake (Merluccius hubbsi) collected from the Patagonian stock in 2005-2014. df=degrees of freedom.

\begin{tabular}{cccl}
\hline & df & Deviance & $P$-value \\
\hline NULL & & 12,931 & \\
Y & 8 & 85.20 & $<0.0001$ \\
TL & 1 & 880.54 & $<0.0001$ \\
SC & 1 & 51.93 & $<0.0001$ \\
$K$ & 1 & 9.94 & $<0.01$ \\
& & &
\end{tabular}

ductive area is evidence of skipped spawning, as was suggested for other species (Rideout and Tomkiewicz, 2011; Rodgveller et al., 2016). The other category of SS commonly described in natural conditions, reabsorbing in prespawning fish, has not been observed in Argentine hake, indicating that once vitellogenesis begins, most of the oocytes would develop through to the end of maturation. Massive atresia probably would be rather associated with species that have a short life cycle because the disruption of gonadal maturation is more common when the environmental conditions are not suitable for spawning. This mechanism would allow fish to divert energy for reproduction to other biological processes, such as growing and migration, until optimal conditions for reproduction are ensured (Rideout et al., 2005; Rideout and Tomkiewicz, 2011).

During January, the female Argentine hake that had skipped spawning were most often observed on the periphery of the main reproductive area, in depths close to $100 \mathrm{~m}$. Considering the entire area covered during the research surveys, the highest proportions of SS females were recorded within the San Jorge Gulf, coinciding with the locations of the main aggregations of juvenile Argentine hake (ÁlvarezColombo et al., 2014). These results may indicate a spatial segregation of SS females during the reproductive season, similar to that reported for Atlantic cod (Gadus morhua) (Rose, 1993). Some authors have suggested that a location of spatial segregation could act as a reservoir for adult specimens of species that are exploited mainly in their spawning areas (Livingston et al., 1997).

The fact that females that had skipped spawning were primarily located on the periphery of the main spawning area, in deeper waters, indicates that the low temperature in this region may be associated with the interruption of the reproductive cycle, if the role of temperature is taken into account in triggering gonadal maturation in fish (Bye, 1984; Rideout et al., 2005). However, it is unknown why these individuals do not move into the coastal area where ripening and spawning of Argentine hake occurs. One possible explanation is that these females choose to remain in the offshore zone in order to feed, as was suggested for a population of Atlantic cod, referred to as "Northeast Arctic cod" (Skjæraasen et al., 2012). In fact, the migratory circuit described for the Patagonia stock of Argentine hake indicates that by the beginning of the reproductive season, Argentine hake move from deeper waters to the coast to spawn and that, once the reproductive activity is completed, spent females return to deeper waters to feed (Macchi et al., 2007).

Our analysis of the incidence of stomachs with contents confirms this hypothesis, given that females that had skipped spawning and postspawning females had the highest percentages of stomachs with food. Results indicate more intense feeding activity by these individuals, but with a very different nutritional condition between maturity stages. Postspawning females had the poorest condition $(K=0.62$ to 0.68 ) because of the energetic cost of reproduction, and females that had skipped spawning had the highest $K$ values (0.68-0.75), partly as a result of the energy saving and reinforced by the sustained feeding activity.

Results from the analysis of the size and age structure for both females that had skipped spawning and reproductive females indicate that females of Argentine hake that had skipped spawning are composed mostly of young fish, 3 years old with a modal size of about $38 \mathrm{~cm}$ TL. The histological information confirms these results with a greater certainty than does the macroscopic diagnosis of gonads alone.

This outcome indicates that a significant proportion of females that have already experienced their first annual spawning could skip the next spawning cycle because age at first maturity for female Argentine 


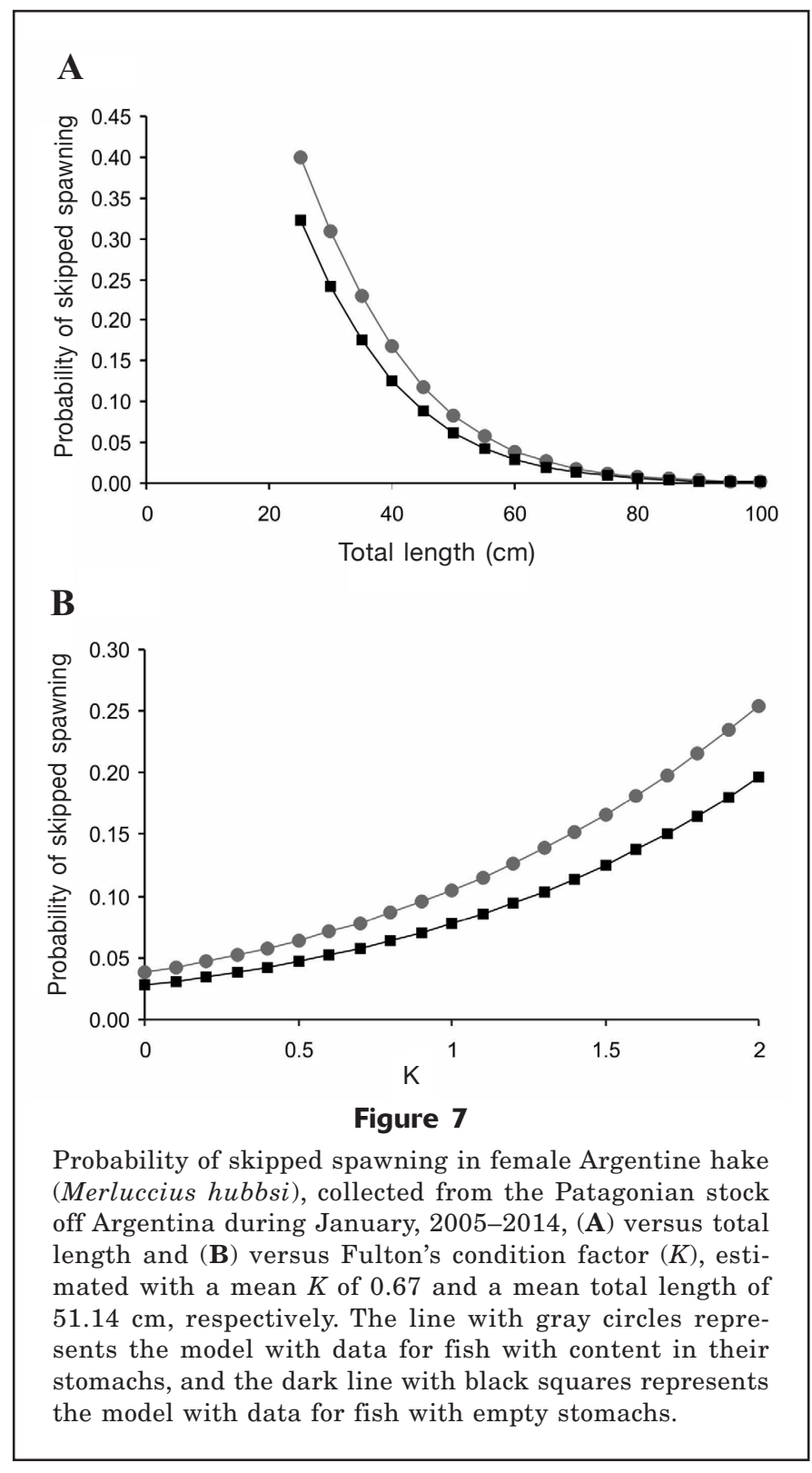

hake was estimated to be 2.6 years (Simonazzi $\left.{ }^{3}\right)$. Jørgensen et al. (2006) suggested that the high proportion of females of Atlantic cod that had skipped spawning corresponds with potential second-time spawners that were unable to fully recover from their first spawning. This pattern of skipped spawning, which mainly affects second-time spawners, has also been suggested for Solea solea (Ramsay and Witthames, 1996), for Atlantic herring (Clupea harengus [Engelhard and Heino, 2005]), and for Atlantic cod from the Northeast Artic

\footnotetext{
${ }^{3}$ Simonazzi, M. 2003. Relación largo-peso y largo-edad de primera madurez sexual de la merluza. In Aportes para la evaluación del recurso merluza (Merluccius hubbsi) al sur de los $40^{\circ}$ S. Año 1999* INIDEP Inf. Téc. 51 (L. S. Tringali and S. I. Bezzi), p. 11-26. Instituto Nacional de Investigación y Desarrollo Pesquero, Mar del Plata, Argentina.
}

(Skjæraasen et al., 2012) and from Canadian waters (Rideout and Rose, 2006). In the latter case, the authors reported that suppression of reproductive activity for this stock of Atlantic cod ranged annually from $8.4 \%$ to $55.6 \%$ of the stock, affecting primarily younger females between 40 and $49 \mathrm{~cm}$ TL. Such results indicate an overestimation of reproductive potential that could reach near $40 \%$, if the proportion of skipped spawning is not considered.

A nutritional deficiency before the beginning of the reproductive season (October-November) could explain why young adult Argentine hake do not begin the annual maturation cycle and stay offshore in the feeding area during the spawning period. In January, during the reproductive peak, these fish will attain a better condition and continue feeding in deeper water. For this reason, the results of generalized linear modeling indicate higher probabilities of females that had skipped spawning with stomach contents because these females were observed mainly offshore, where the feeding activity is more intense. The relationship between the proportion of females that had skipped spawning and total length also showed a higher probability that individuals would not spawn while having food in their stomachs for fish with lengths smaller than $60 \mathrm{~cm}$ TL. In specimens larger than $60 \mathrm{~cm}$ TL, the probability of skipped spawning decreased for both females with food in their stomachs, as well as for those with empty stomachs.

These results indicate that not only larger females are reproductively active during January but also that some of them are actively feeding. In other words, larger female Argentine hake had a higher incidence of both spawning and feeding during the reproductive season than had young females, as has been previously suggested for this stock (Macchi et al., 2013).

The analyzed data do not allow an accurate estimation of the percentage of adult females that skip the annual spawning because the research surveys did not cover the entire spatial distribution of the Patagonian stock of Argentine hake. Estimates of the percentage of females that skip spawning for the reproductive area (see Fig. 1) ranged between $4 \%$ and $10 \%$ of the adult females sampled during January between 2005 and 2014, but these values markedly increase when data from San Jorge Gulf were included, reaching as high as $22 \%$ in some years. However, it is important to mention that, because females that skip spawning were primarily represented by young females, the overestimation of reproductive potential may have been lower than expected because both relative fecundity and egg quality are lower in female Argentine hake smaller than $50 \mathrm{~cm}$ TL (Macchi et al., 2013).

The Argentine hake is a species with indeterminate annual fecundity, i.e., with the capacity to continually recruit oocytes into the vitellogenic phase in an extended breeding season; therefore, it is possible 


\section{Table 5}

Results of the principal component (PC) analysis of environmental data collected during the research surveys conducted in the spawning area of the Patagonian stock of Argentine hake (Merluccius hubbsi) between 2005 and 2014. Values of the eigenvectors and percentage of the variance explained by the original data set (coefficient of determination $\left.\left[r^{2}\right]\right)$. Employed variables were percentage of skipped spawning (\% SS), percentage of spawning females (\% S), bottom temperature (BT), surface temperature (ST); bottom salinity (BS), surface salinity (SS), and depth (D).

\begin{tabular}{lrr}
\hline Variables & PC1 & PC2 \\
\hline$\%$ SS & 0.39 & 0.13 \\
$\%$ S & -0.38 & -0.12 \\
BT $\left({ }^{\circ} \mathrm{C}\right)$ & -0.42 & -0.39 \\
ST $\left({ }^{\circ} \mathrm{C}\right)$ & -0.36 & 0.35 \\
BS & -0.22 & 0.60 \\
SS & -0.39 & 0.43 \\
D & 0.45 & 0.38 \\
$r^{2}$ & 0.42 & 0.22 \\
\hline
\end{tabular}

that some females complete their gonadal maturation and their spawning outside of the normal reproductive period, as suggested by Rideout and Tomkiewicz (2011). However, we consider it unlikely that females that skipped spawning found in January could begin the process of maturation and spawning before the environmental conditions become adverse for the growth and survival of the Argentine hake larvae. Moreover, it is noteworthy that previous histological studies performed throughout the breeding season documented the existence of females that had skipped spawning during the entire spawning period and an increase in skipped spawning toward the end of the reproductive season (Macchi et al., 2004; Pájaro et al., 2005).

Data presented here indicate that skipped spawning may be a common phenomenon in the Patagonian stock of Argentine hake and that it may be a mechanism that allows a species to regulate its energy needs for future spawning, as has been suggested for many other fish (Rideout and Tomkiewicz, 2011; Skjæraasen et al., 2012, 2015). However, from a fisheries assessment point of view, the effect of skipped spawning on SSB estimates should be considered. For this reason, it is necessary to continue and expand studies of this phenomenon in Argentine hake, a species that is a resource of great economic importance for Southwest Atlantic fisheries. Understanding this process, together with estimates of its incidence throughout the entire Patagonian stock of Argentine hake, may help to explain the wide variation in the stock-recruitment relationships reported for this species. Moreover, further field research is needed to understand why some individuals decide to skip spawning and some do not. For this reason, an analysis of the biochemical composition of different tissues and determination of the physiological status and feeding activity of individuals before the beginning of maturation may help to improve understanding of the mechanisms that regulate the origin and frequency of skipped spawning in Argentine hake.

\section{Acknowledgments}

We wish to thank M. Estrada and H. Brachetta for preparation of the histological sections and we give special thanks to M. Iorio and C. Dato for their help during sample collection and to the technical staff of the Hake Assessment Group of the INIDEP for age determination. We wish to express our appreciation for the in-depth comments, suggestions, and corrections made by reviewers that greatly improved the manuscript. This work was supported by the INIDEP, Consejo Nacional de Investigaciones Científicas y Técnicas (PIP 112201201 00047), and Fondo para la Investigación Científica y Tecnológica (PICT-2013-1484). INIDEP contribution No. 1985.

\section{Literature cited}

Álvarez-Colombo, G. L., C. V. Dato, L. Machinandiarena, F. Castro-Machado, and P. Betti.

2014. Daylight vertical segregation of young-of-the-year Argentine hake Merluccius hubbsi: advances in assessment of juvenile abundance with acoustic methods. Fish. Res. 160:85-95. Article

Brown-Peterson, N. J., D. M. Wyanski, F. Saborido-Rey, B. J. Macewicz, and S. K. Lowerre-Barbieri.

2011. A standardized terminology for describing reproductive development in fishes. Mar. Coast. Fish. 3:52-70. Article

Bye, V. J.

1984. The role of environmental factors in the timing of reproductive cycles. In Fish reproduction: strategies and tactics (G. W. Potts and R. J. Wootton, eds.), p. 187206. Academic Press, London.

Dutil, J. D.

1986. Energetic constraints and spawning interval in the anadromous Arctic charr (Salvelinus alpinus). Copeia 1986:945-955. Article

Engelhard, G. H., and M. Heino.

2005. Scale analysis suggests frequent skipping of the second reproductive season in Atlantic herring. Biol. Lett. 1:172-175. Article

Holmgren, K.

2003. Omitted spawning in compensatory-growing perch. J. Fish Biol. 62:918-927. Article

Hunter, J. R., B. J. Macewicz, N. C.-H. Lo, and C. A. Kimbrell. 1992. Fecundity, spawning, and maturity of female Dover sole Microstomus pacificus, with an evaluation of assumptions and precision. Fish. Bull. 90:101-128.

Jørgensen, C., B. Ernande, Ø. Fiksen, and U. Dieckmann. 2006. The logic of skipped spawning in fish. Can. J. Fish. Aquat. Sci. 63:200-211. Article

Kennedy, W. A.

1953. Growth, maturity, fecundity and mortality in the relatively unexploited whitefish, Coregonus clupeafor- 
mis, of Great Slave Lake. J. Fish. Res. Board. Can. 10:413-441. Article

Livingston, M. E., M. Vignaux, and K. A. Schofield.

1997. Estimating the annual proportion of nonspawning adults in New Zealand hoki, Macruronus novaezelandiae. Fish. Bull. 95:99-113.

Macchi, G. J., and M. Pájaro.

2003. Comparative reproductive biology of some commercial marine fishes from Argentina. Fisk. Havet 12:69-77.

Macchi, G. J., M. Pájaro, and M. Ehrlich.

2004. Seasonal egg production pattern of the Patagonian stock of Argentine hake (Merluccius hubbsi). Fish. Res. 67:25-38. Article

Macchi, G. J., M. Pájaro, and C. Dato.

2007. Spatial variations of the Argentine hake (Merluccius hubbsi) spawning shoals in the Patagonian area during a reproductive season. Rev. Biol. Mar. Oceanogr. 42:345-356.

Macchi, G. J., E. Leonarduzzi, M. V. Diaz, M. Renzi, and K. Rodrigues.

2013. Maternal effects on the fecundity and egg quality of the Patagonian stock of Argentine hake (Merluccius hubbsi). Fish. Bull.111:325-336. Article

Mace, P. M., and M. P. Sissenwine.

1993. How much spawning per recruit is enough? In Risk evaluation and biological reference points for fisheries management (S. J. Smith, J. J. Hunt, and D. Rivard, eds.), p. 101-118. Can. Spec. Publ. Fish.Aquat.Sci. 120, 442 p.

Pájaro, M., G. J. Macchi, and P. Martos.

2005. Reproductive pattern of the Patagonian stock of Argentine hake (Merluccius hubbsi). Fish. Res. 72:97-108. Article

Ramsay, K., and P. Witthames.

1996. Using oocyte size to assess seasonal ovarian development in Solea solea (L.). J. Sea Res. 36:275-283. Article

$\mathrm{R}$ Core Team.

2015. R: a language and environment for statistical computing. R Foundation for Statistical Computing, Vienna, Austria. [Available at website, accessed December 2015.]

Renzi, M. A., and M. A. Pérez.

1992. Un criterio para la determinación de la edad en juveniles de merluza (Merluccius hubbsi) mediante la lectura de otolitos. Frente Marít. 11:15-31.
Rideout, R. M., and G. A. Rose.

2006. Suppression of reproduction in Atlantic cod Gadus morhua. Mar. Ecol. Progr. Ser. 320:267-277. Article

Rideout, R. M., and J. Tomkiewicz.

2011. Skipped spawning in fishes: More common than you might think. Mar. Coast.Fish. 3:176-189. Article

Rideout, R. M., M. P. Burton, and G. A. Rose.

2000. Observations on mass atresia and skipped spawning in northern Atlantic cod, from Smith Sound, Newfoundland. J. Fish Biol. 57:1429-1440. Article

Rideout, R. M., G. A. Rose, and M. P. M. Burton.

2005. Skipped spawning in female iteroparous fishes. Fish Fish. 6:50-72. Article

Rideout, R. M., M. J. Morgan, and G. R. Lilly.

2006. Variation in the frequency of skipped spawning in Atlantic cod (Gadus morhua) of Newfoundland and Labrador. ICES J. Mar. Sci. 63:1101-1110. Article

Rodgveller, C. J., J. W. Stark, K. B. Echave, and P.-J. F. Hulson. 2016. Age at maturity, skipped spawning, and fecundity of female sablefish (Anoplopoma fimbria) during the spawning season. Fish. Bull. 114:89-102. Article

Rose, G. A.

1993. Cod spawning on a migration highway in the northwest Atlantic. Nature 366:458-461. Article

Skjæraasen, J. E., J. Kennedy, A. Thorsen, M. Fonn, B. N. Strand, I. Mayer, and O. S. Kjesbu.

2009. Mechanisms regulating oocyte recruitment and skipped spawning in Northeast Arctic cod (Gadus morhua). Can. J. Fish. Aquat. Sci. 66:1582-1596. Article

Skjæraasen J. E., R. D. M. Nash, K. Korsbrekke, M. Fonn, T. Nilsen, J. Kennedy, K. H. Nedreaas, A. Thorsen, P. R. Witthames, A. J. Geffen, et al.

2012. Frequent skipped spawning in the world's largest cod population. Proc. Natl. Acad. Sci. U.S.A. 109:8995-8999. Article

Skjæraasen J. E., K. Korsbrekke, T. Nilsen, M. Fonn, O. S. Kjesbu, G. E. Dingsør, and R. D. M. Nash.

2015. Skipped spawning in Northeast Arctic haddock Melanogrammus aeglefinus. Mar. Ecol. Progr. Ser. 526:143-155. Article

Trippel, E. A.

1999. Estimation of stock reproductive potential: history and challenges for Canadian Atlantic gadoid stock assessments. J. Northw. Atl. Fish. Sci. 25:61-81. 